\title{
Long non-coding RNAs regulate drug resistance in cancer
}

\author{
Kaisheng Liu ${ }^{1 \dagger}$, Lin Gao ${ }^{1 \dagger}$, Xiaoshi Ma", Juan-Juan Huang ${ }^{1}$, Juan Chen ${ }^{1}$, Leli Zeng ${ }^{3,4}$, Charles R. Ashby Jr. ${ }^{3}$, \\ Chang Zou ${ }^{1 *}$ and Zhe-Sheng Chen ${ }^{3^{*}}$ (I)
}

\begin{abstract}
Chemoresistance, whether intrinsic or acquired, is a major obstacle in the treatment of cancer. The resistance of cancer cells to chemotherapeutic drugs can result from various mechanisms. Over the last decade, it has been reported that 1ong noncoding RNAs (IncRNAs) can mediate carcinogenesis and drug resistance/sensitivity in cancer cells. This article reviews, in detail, recent studies regarding the roles of IncRNAs in mediating drug resistance.
\end{abstract}

Keywords: Cancer, Drug resistance, Long non-coding RNAs

\section{Background}

Globally, cancer is the leading cause of mortality and in 2018, it was estimated that there were 9.6 million cancer-related deaths [1]. Currently, the primary therapeutic approaches for treating cancer are chemotherapy, radiation and surgery [2]. However, during treatment, tumor cells can become resistant to chemotherapy due to, but not limited to; 1 ) increased expression of certain ATP-binding cassette $(\mathrm{ABC})$ transport proteins that decrease the intracellular concentration of anticancer drugs, thereby decreasing their efficacy; 2) alterations that allow cancer cells to avoid cell death; 3 ) increase in DNA repair; 4) mutations in specific cellular targets; 5) alterations that allow cancer cells to tolerate adverse or stressful conditions and 6) increasing the biotransformation of anticancer drugs to less efficacious or inactive metabolites [3]. Consequently, drug resistance is still a major challenge as it often causes therapeutic failure [4].

\footnotetext{
*Correspondence: zou.chang@szhospital.com; chenz@stjohns.edu ${ }^{\dagger}$ Kaisheng Liu, Lin Gao and Xiaoshi Ma contributed equally to this work. ${ }^{1}$ The First Affiliated Hospital of Southern University of Science and Technology, The Second Clinical Medical College of Jinan University, Shenzhen People's Hospital, Shenzhen 518020, Guangdong, People's Republic of China

${ }^{3}$ College of Pharmacy and Health Sciences, St. John's University, Queens, New York, NY 11439, USA

Full list of author information is available at the end of the article
}

Furthermore, drug resistance can be present in tumor cells before chemotherapy, a phenomenon known as acquired drug resistance [5]. Overall, the underlying mechanisms of resistance to chemotherapeutic drugs remain to be fully elucidated.

The development of new technologies, in combination with bioinformatics, has resulted in the discovery of additional genes associated with drug resistance [6]. Furthermore, it is important to note that $<2 \%$ of the human genome encodes proteins and $98 \%$ of the transcriptional products are short and long non-coding RNAs (lncRNAs) [7, 8]. LncRNAs consist of more than 200 nucleotides and have no protein coding function [7]. LncRNAs are less conserved among species, are typically expressed at low levels and often have high tissue and development specificity [9]. LncRNAs have important regulatory roles in many aspects of genome function, including gene transcription, splicing, and epigenetics, as well as biological processes involved in the cell cycle, cell differentiation, development, and pluripotency [10]. LncRNAs have recently been identified as a new mechanism in drug resistance/sensitivity and has garnered significant attention in the area of cancer research. Indeed, numerous papers have been published over the last decade regarding lncRNA and resistance to anticancer drugs. In this review, we will discuss the mechanisms 
by which lncRNAs produce drug resistance in cancer cells.

\section{LncRNA roles in mediating resistance to anticancer drugs} The effect of InCRNA on phase I and phase II enzymes

Alterations in drug metabolism are one of the important and most studied mechanisms that mediate drug resistance. The mechanisms of drug metabolism and disposition can be categorized as: phase I, phase II and phase III [11]. LncRNAs can regulate certain phase I enzymes and affect drug resistance in cancer cells. For example, lncRNA H19 is overexpressed in colorectal cancer and increases the intracellular aldehyde dehydrogenase (ALDH) activity in colorectal tumors [12]. LncRNA H19 activates the $\beta$-catenin pathway by sequestering miR141, which contributes to tumor development and chemoresistance in colorectal cancer tumors [12].

LncRNAs have been shown to affect the regulation of specific phase II enzymes [13, 14]. The expression of the IncRNA, HOX transcript antisense intergenic RNA (HOTAIR), is positively correlated with the level of the carbohydrate sulfotransferase (CHST15) protein in primary, as well as the number of metastatic tumor lesions [13]. In addition, HOTAIR promotes the invasion of breast cancer cells by affecting the expression of cell surface glycosaminoglycans [13]. The lncRNA Homo sapiens glutathione S-transferase mu 3, transcript variant 2 and noncoding RNA (GSTM3TV2) levels are significantly increased in pancreatic tumor tissues and it upregulates the L-type amino acid transporter 2 (LAT2) and oxidized low-density lipoprotein receptor 1 (OLR1) by competitively sequestering let-7 (a mRNA targeting cMyc, HMGA2 and Ras) to induce gemcitabine resistance in pancreatic cancer [15].

\section{Altered drug efflux and related IncRNAs}

In phase III drug disposition, the metabolites of the drugs are eliminated and excreted by various endogenous transporters that are found in the liver, small intestine, brain and kidney, which play a role in protecting tissues and organs from endogenous and xenobiotics $[16,17]$. It is well established that the overexpression of the $A B C$ proteins by cancer cells, which efflux anticancer drugs from the cancer cells, thereby attenuating or abrogating their efficacy, mediates resistance to certain anticancer drugs $[18,19]$. Numerous studies indicate that the members of the $\mathrm{ABC}$ transporter family associated with multidrug resistance (MDR) in cancer cells include p-glycoprotein (P-gp/ABCB1), MRP1/ABCC1, MRP2/ABCC2, MRP4/ABCC4, and BCRP/ABCG2 [20] (Fig. 1).

Recent studies have shown that specific lncRNAs can affect various $\mathrm{ABC}$ transporters, thereby producing drug resistance. For example, in hepatocellular cancer (HCC), knockdown of lncRNA H19 significantly increased the methylation of the MDR1 promoter methylation and decreased MDR1/P-glycoprotein expression in doxorubicin (DOX)-resistant R-HepG2 cells [21]. In addition, the levels of lncRNA very low density lipoprotein receptor (VLDLR) are significantly increased in HCC, and the knockdown of lncRNA VLDLR significantly reduced HCC proliferation and the expression of BCRP/ABCG2, while overexpression of BCRP/ABCG2 decreased the effect of lncRNA VLDLR1 knockdown on sorafenibinduced cell death in HepG2 cells [22]. The lncRNA plasmacytoma variant translocation 1 (PVT1) is highly expressed in gastric cancer tissues of cisplatin-resistant patients and cisplatin-resistant cells [23]. The upregulation of lncRNA PVT1 increased the expression of MDR1, MRP, mammalian target of rapamycin (mTOR) and hypoxia-inducible factor alpha (HIF-1 $\alpha$ ) and decreased the apoptosis produced by cisplatin in BGC823 and SGC7901 cancer cells [23]. The lncRNA MDRrelated and upregulated IncRNA (MRUL) was significantly upregulated in the multidrug-resistant gastric cancer cell sublines, SGC7901/ADR [resistant to doxorubicin/adriamycin (DOX/ADR)] and SGC7901/VCR [resistant to vincristine (VCR)], and its expression

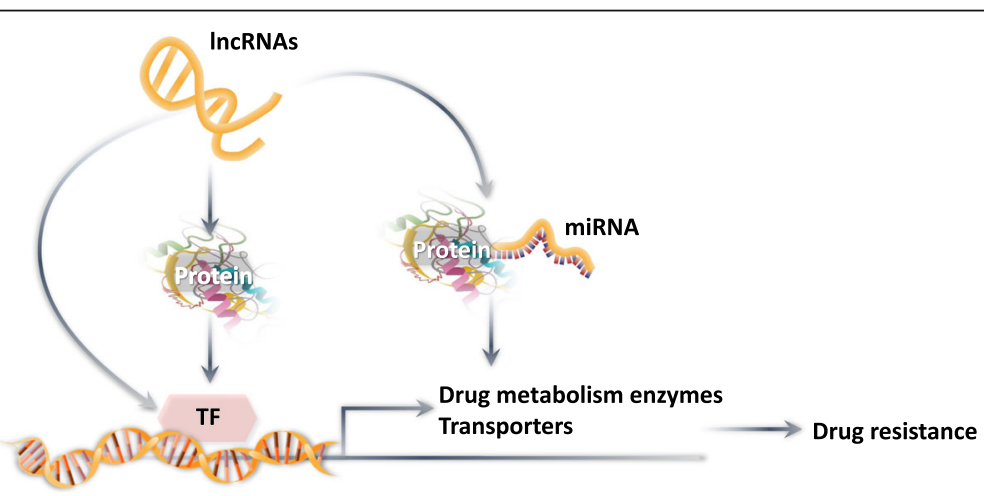

Fig. 1 Schematic illustration of IncRNA-induced resistance to anticancer drugs by altering drug metabolism and drug efflux 
significantly decreased the anti-proliferative efficacy of ADR or VCR [24]. The expression of IncRNA MRUL increases the expression of P-gp/ABCB1 in an orientationand position-independent manner and the depletion of MRUL decreased ABCB1 mRNA levels in a concentration - and time-dependent manner [24]. In addition, the knockdown of lncRNA AK022798 downregulated the expression of MRP1/ABCC1 and P-gp/ABCB1, and increased apoptosis and the expression of caspase -3 and caspase -8 in the cisplatin-resistant gastric cancer cell lines, SGC7901/DDP and BGC823/DDP [25]. The lncRNA metastasis-associated lung adenocarcinoma transcript 1 (MALAT1) significantly upregulates MRP1/ ABCC1 and MDR1/ABCB1 by activating STAT3 in a cisplatin (DDP) resistant non-small cell lung cancer cells [26]. The lncRNA antisense non-coding RNA in the INK4 locus (ANRIL) was highly expressed in the gastric cancer tissues of cisplatin-resistant and 5-fluorouracil (5FU)-resistant patients, and in cisplatin-resistant cells (BGC823/DDP) and 5-FU-resistant cells (BGC823/5-FU) [27]. The knockdown of the lncRNA ANRIL decreased the expression of MDR1/ABCB1 and MRP1/ABCC1, and increased the efficacy of cisplatin or 5-FU in the cisplatinresistant cell line, BGC823/DDP or the 5-FU-resistant cells, BGC823/5-FU [27]. The lncRNA KCNQ1OT1 is highly expressed in lung adenocarcinoma cells and the knockdown of lncRNA KCNQ1OT1 significantly decreased the expression of MDR1/ABCB1 in A549 adenocarcinomic human alveolar basal epithelial/human ovary cells derived from metastatic site (PA1) cells [28]. The knockdown of lncRNA X-inactive specific transcript (XIST) upregulates miR-124 and downregulates serum and glucocorticoidinducible kinase 1 (SGK1), which increases the in vivo efficacy of DOX in colorectal cancer cells by facilitating DOXinduced apoptosis [29]. The expression of both lncRNA linc00518 and MRP1/ABCC1 are significantly increased in human breast cancer tissues compared to normal adjacent tissues [30]. The downregulation of lncRNA linc00518 increased the efficacy of DOX, vincristine and paclitaxel in MCF-7 breast cancer cells resistant to ADR and increased the anti-tumor efficacy of ADR in vivo by regulating miR199a/MRP1 axis in MCF-7/ADR cells [30]. Finally, the IncRNA bladder cancer associated transcript-1 (BLACAT1) decreases the efficacy of oxaliplatin, a P-gp/ABCB1 substrate, by increasing the expression of the $A B C B 1$ protein via sponging miR-361, which targets 3'-UTR of BLACAT1 and ABCB1 mRNA [31].

\section{The inhibition of apoptosis by IncRNAs}

Numerous studies have shown that the majority of chemotherapeutic drugs used in the treatment of cancer induce cell death by activating apoptosis pathways and the dysregulation of apoptosis produces drug resistance and enhance the survival of cancer cells [32, 33]. Recently, the expression levels of lncRNAs have been reported to be significantly correlated with drug resistance in various tumors. The lncRNA E2F1-regulated inhibitor of cell death (ERIC) is a $1.7 \mathrm{~kb}$ transcript up-regulated by E2F1 [34]. The knockdown of ERIC significantly increases etoposide-induced apoptosis in osteosarcoma cells incubated with etoposide, suggesting that ERIC plays a role in mediating etoposide resistance [34]. The loss of lncRNA p53-dependent apoptosis modulator (PDAM) increased the expression of the anti-apoptotic protein, BCL-2, which induces cisplatin resistance in oligodendroglial tumors (Fig. 2) [35]. The overexpression of the lncRNA prostate cancer gene expression marker 1 (PCGEM1) produces resistance to DOX-induced apoptosis by suppressing the cleavage of caspase -7 in LNCaP (cancer cells isolated from the lymph node of a patient with prostate cancer) (Fig. 2) [36]. The lncRNA cancer upregulated drug resistant gene (CUDR) is an urothelial cancer associated 1 (UCA1) transcript variant that is upregulated in many types of tumors [37]. The overexpression of CUDR inhibits apoptosis induced by cisplatin and increases tumorigenesis in bladder cancer cells [37]. Moreover, CUDR produces resistance to DOX and etoposide in squamous cell cancer [38].

\section{The repair of damaged DNA by IncRNAs}

DNA damage, which is produced by ultraviolet radiation, ionizing radiation and genotoxic chemicals, occurs on a constant basis [39]. DNA damage can be repaired or tolerated in normal cells so as to maintain cellular and organ functions [40]. However, recurrent chemoresistant cancer cells activate the DNA damage response more efficiently and have a higher tolerance in genotoxic stress environments produced by chemotherapeutic drugs compared to primary cancer cells [41].

Several lines of evidence indicate that lncRNA expression is significantly altered in drug resistant cancers. Cisplatin, which damages DNA and induces cell death, is a commonly used chemotherapeutic drug for the treatment of non-small cell lung cancer (NSCLC) [42]. The lncRNA DNA damage-sensitive RNA1 (DDSR1), by interacting with BRCA1 and hnRNPUL1, increases DNA repair by inducing homologous recombination, thereby increasing cisplatin resistance in NSCLC (Fig. 2) [43, 44]. Furthermore, a number of p53-regulated lncRNAs are stimulated in response to DNA damage induced by chemotherapeutic drugs. The lncRNA p21 associated ncRNA DNA damage activated (PANDA) is activated by p53 and interacts with the protein, nuclear transcription factor Y subunit alpha (NFYA, one of the subunits of the trimeric protein, NF-Y, that interacts with CCAAT motifs in promoter regions [45]) to inhibit DNA damage-induced apoptosis in FL3 cells incubated with DOX [46]. The IncRNA HOTAIR produces cisplatin resistance in NSCLC by downregulating p21, an inhibitor 


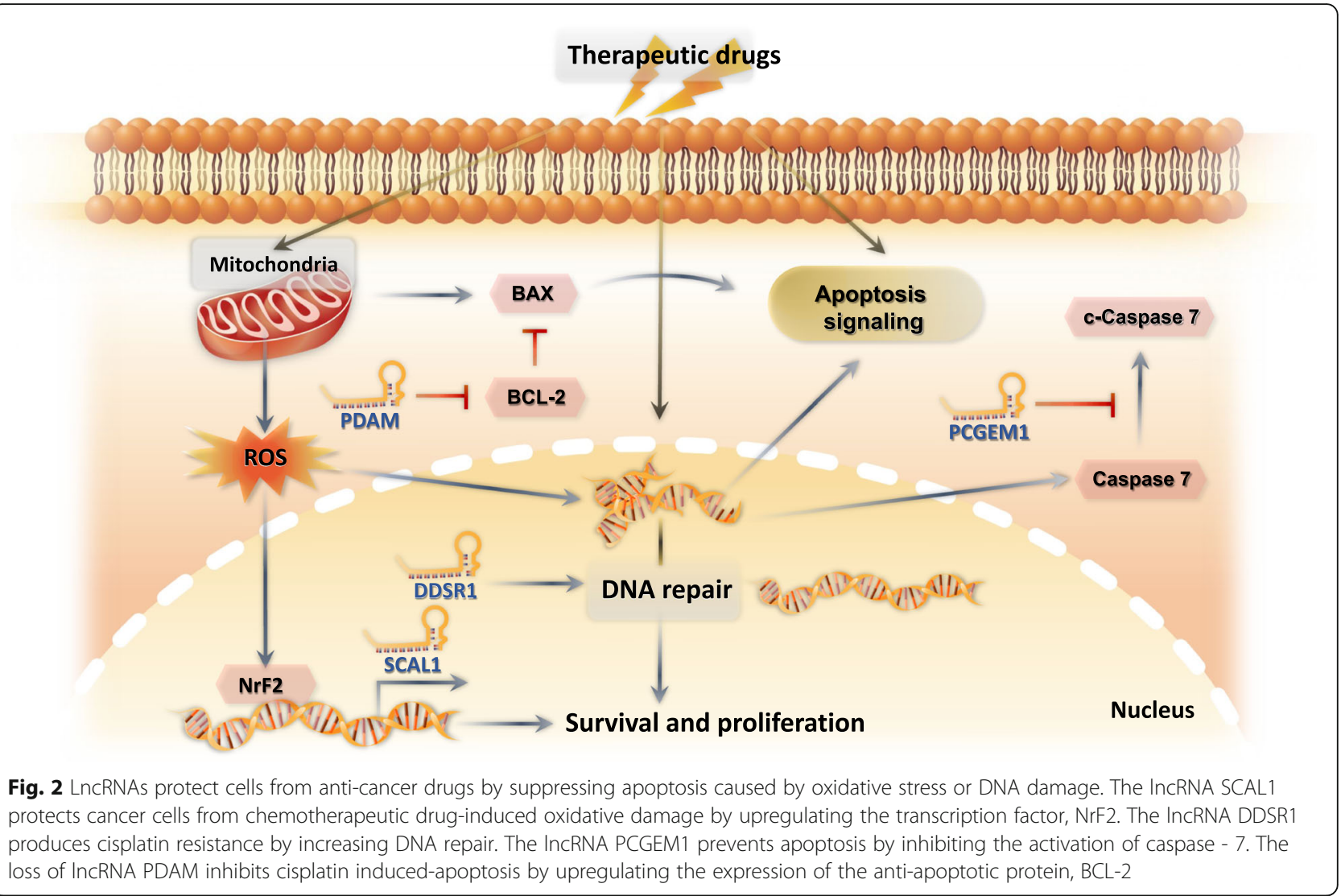

of cyclin-dependent kinase that causes cell cycle arrest after DNA damage or overexpression of p53 [47, 48].

\section{Oxidative stress and IncRNAs}

Reactive oxygen species (ROS) are cell signaling molecules produced in mitochondria during normal cell metabolisms and high concentrations of ROS can cause oxidative stress, producing cytotoxicity in certain cellular environments [49-51]. Aberrant or dysregulated ROS-scavenging systems in cancer can decrease the susceptibility to oxidative stress, resulting in drug resistance [52].

LncRNAs play essential roles in the cellular response to oxidative stress. The ncRNA smoke and cancerassociated lncRNA-1 (SCAL1) is up-regulated by the protein transcription factor, nuclear factor erythroid 2related factor 2 (Nrf2) in different lung cancer cell lines [53]. As Nrf2 plays an important role in protecting normal cells from oxidative stresses and mediating chemoresistance in certain cancer cells, SCAL1's increased expression in lung cancer cells suggests that it may provide protection from oxidative stress induced by certain chemotherapeutic drugs (Fig. 2) [53, 54]. The lncRNA transient receptor potential cation channel subfamily $M$ member 2 antisense (TRPM2-AS) codes for an oxidative stress-activated ion channel that regulated cell survival
[55]. The lncRNA TRPM2-AS is overexpressed in the prostate cancer cell line, PC3, and its knockdown induced PC3 apoptosis and increased the intracellular levels of hydrogen peroxide, a potent oxidative molecule [55]. Furthermore, recent studies indicate that TRPM2 may have a protective effect in cells exposed to moderate oxidative stress $[56,57]$ (Table 1).

\section{Alterations in drug targets by IncRNAs}

There is accumulating evidence indicating that there is heterogeneity among various carcinoma cells, such as pancreatic [59], breast [60], and prostate [61]. Cancer stem cells (CSCs) have the capacity for self-renewal and they differentiate to produce cancer cells [62]. Cancer cells derived from CSC have genes that when expressed, induce epithelial-mesenchymal transition (EMT), which plays an important role in mediating metastasis $[62,63]$. Emerging evidence suggests that lncRNAs mediate tumorigenesis and drug resistance in certain types of cancers. Below, we will discuss the potential of lncRNAs as novel therapeutic targets for chemoresistance and targeted drug therapy to prevent and treatment drugresistant cancers.

Gefitinib is a tyrosine kinase inhibitor (TKI) that antagonizes the epidermal growth factor receptor (EGFR) [64]. However, it has been previously reported that 
Table 1 LncRNAs-induced cell death in drug - resistant cancer cells

\begin{tabular}{|c|c|c|c|c|}
\hline LncRNA & Cancer type & $\begin{array}{l}\text { Drug } \\
\text { resistant }\end{array}$ & Mechanisms & Ref \\
\hline ERIC & Osteosarcoma & Etoposide & ERIC inhibits DNA damage-induced apoptosis & [34] \\
\hline PDAM & $\begin{array}{l}\text { Oligodendroglial } \\
\text { tumor }\end{array}$ & Cisplatin & Loss of PDAM inhibits apoptosis by increasing the expression of $B C L-2$ & [35] \\
\hline PCGEM1 & Prostate cancer & DOX & Overexpression of PCGEM1 inhibits apoptosis by suppressing the activation of caspase 7 & [36] \\
\hline CUDR & Bladder cancer & Cisplatin & Overexpression of CUDR suppresses DNA damage-induced apoptosis & [37] \\
\hline DDSR1 & $\begin{array}{l}\text { Non-small cell lung } \\
\text { cancer }\end{array}$ & Cisplatin & $\begin{array}{l}\text { DDSR1 inhibits DNA damage-induced apoptosis by promoting DNA repair with homologous } \\
\text { recombination }\end{array}$ & [43] \\
\hline HOTAIR & $\begin{array}{l}\text { Non-small cell lung } \\
\text { cancer }\end{array}$ & Cisplatin & HOTAIR contributes to cisplatin resistance via downregulation of P21 & [58] \\
\hline SCAL1 & $\begin{array}{l}\text { Non-small cell lung } \\
\text { cancer }\end{array}$ & Gefitinib & SCAL1 is overexpressed in lung cancer cells with elevated expression of NrF2 & $\begin{array}{l}{[53,} \\
54]\end{array}$ \\
\hline
\end{tabular}

cancer cells can develop resistance to gefitinib during treatment by the following mechanisms: a second mutation in the EGFR protein [65], c-MET amplification [66], changes in signaling pathways, such asIL-6/JAK1/STAT3 [67], PIK3CA [68] and IGF1R [69], activating mutations, RAS-MAPK pathway activation [70], and by alterations in the tumor microenvironment [71]. A recent study reported that gefitinib resistance in NSCLC is mediated by the overexpression of LINC00665 and that the loss of LINC00665 reduces the activation of the EGFR and Akt pathways (which decreases cell proliferation and survival) by interacting with the enhancer of the zeste 2 polycomb repressive complex 2 subunit (EZH2) [72].

Specific drug targets of IncRNAs have been reported to affect the progression stages in prostate cancer $(\mathrm{PCa})$ [73]. In addition, since the emergence of next-generation sequencing, there is evidence indicating that $\mathrm{PCa}$ is a molecularly heterogeneous cancer [61]. The most salient therapeutic target in $\mathrm{PCa}$ is the androgen receptor (AR) [74]. In hormone-sensitive $\mathrm{PCa}, \mathrm{AR}$ signaling is regulated by lncRNAs, such as HOTAIR, which represses the degradation of the E3-ubiquintin - AR complex, which induces castration resistant prostate cancer (CRPC) to promote metastasis of cancer cells [75]. Gu et al. [73] reported that the lncRNA bladder and prostate cancer suppressor (LBCS) protein is overexpressed CRPC cells and tissues, which inhibits $\mathrm{PCa}$ growth under castration conditions by blocking AR signaling [73]. In hormone sensitive $\mathrm{PCa}$, transforming growth factor-beta (TGFbeta) activates the expression of the long noncoding RNA activated by TGF-beta (nncRNA-ATB), which upregulates the levels of certain EMT molecules in CRPC and increases cyclin D1 and cyclin E levels which increase cell proliferation and EMT [76]. In contrast, the differentiation antagonizing non-protein coding RNA (DANCR) produces an accelerated terminal differentiation of normal prostate epithelial cells and reverses AR signaling, repressing the metastasis in PCa cells $[77,78]$. Thus, it is possible that PCa metastasis may be mediated by positive or negative lncRNAs, depending on the subtype of hormone-sensitive receptors. Furthermore, the lncRNA AR splice variant 7 and AS region of $\mathrm{C}$-terminal binding protein 1 (CTBP1-AS) downregulates CTBP1 expression by recruiting the RNA-binding transcriptional repressor, PSF, and together with histone deacetylases, accelerates progression to CRPC in PCa cells [79, 80]. Recently, Ta et al. [81] reported a significant positive correlation between the expression of the novel hormone-upregulated IncRNA within LCK (HULLK) and resistance to AR signaling. HULLK is encoded within the lymphocyte-specific protein tyrosine kinase (LCK), which is regulated by androgen receptors [81]. In the presence of AR, the loss of HULLK significantly decreased cancer cells proliferation, whereas the overexpression of HULLK increased the sensitivity of PCa cells to AR in CRPC [81]. Overall, these data may be useful in finding novel biomarkers or more effective therapeutic targets for clinically resistant $\mathrm{PCa}$.

\section{The effect of IncRNAs on EMT in the cytoplasm and the nucleus}

The EMT plays an important role in cancer progression, metastasis and drug resistance $[59,82]$. In various cancers, EMT is defined as the transformation from epithelial cells to a mesenchymal phenotype [82] (Fig. 3).

Recent studies have shown a significant positive correlation between the expression of EMT and CSCs and an increase in cancer cell metastasis and resistance [83]. In aggressive cancer cells, the expression of EMT markers increased the stemness of tumor-initiating CSCs and the magnitude of invasiveness and metastasis [59].

LncRNAs mediate pathophysiological processes associated with hepatocellular carcinomas and regulate invasiveness and drug resistance. The lncRNA miR503HG is minimally expressed in $\mathrm{HCC}$ and when expressed at high levels, it inhibits HCC metastasis by regulating the heterogeneous nuclear ribonucleoprotein A2/B1 (HNRNPA2B1)/ NF-kB signaling pathway [84]. 


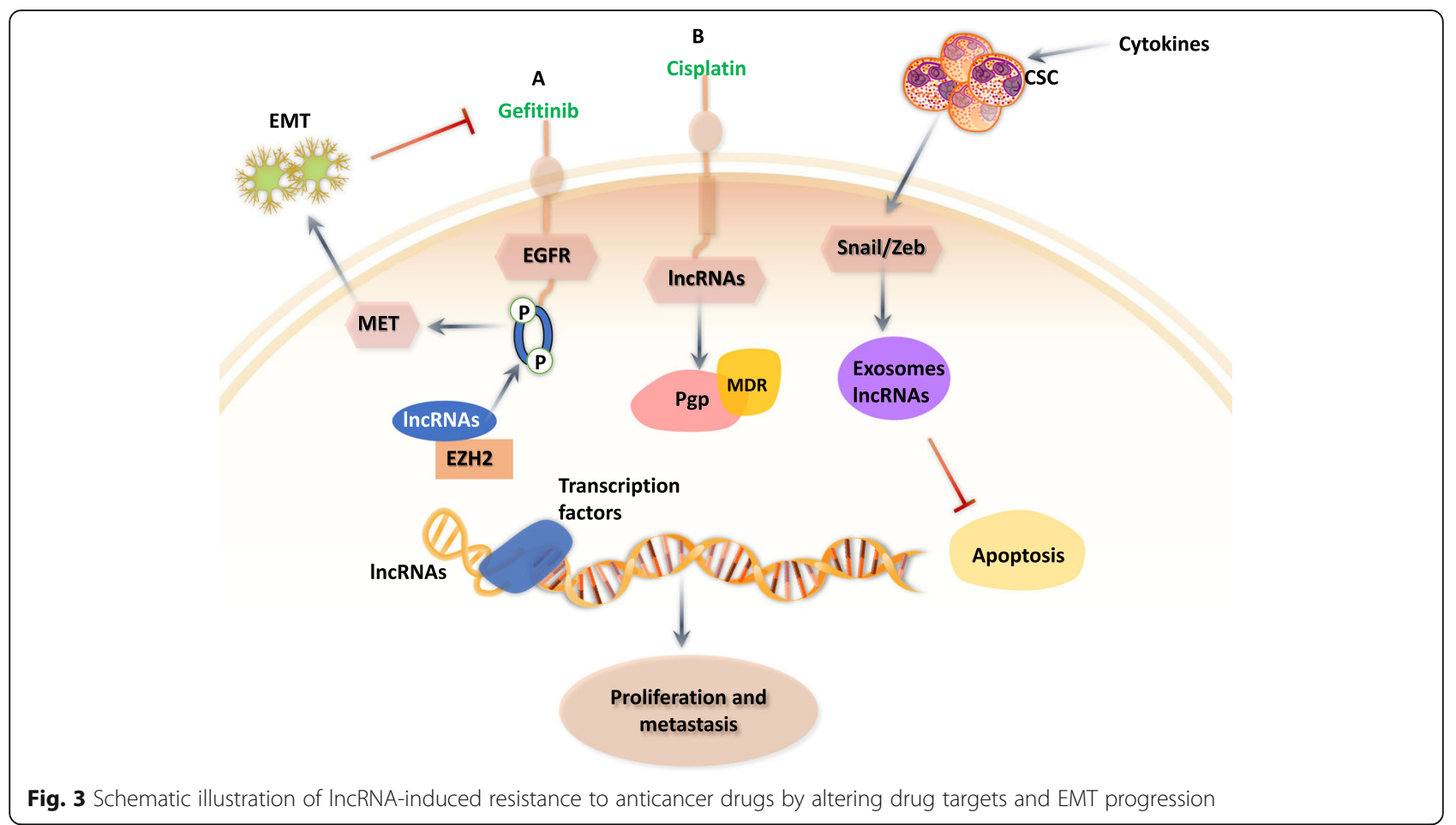

In squamous cell carcinomas (SCCs), such as esophagus, head and neck, lung and skin cancers, lncRNA have "super-enhancer" regions that are involved in inducing the expression of certain genes. For example, the transcription factors, tumor protein p63 (TP63) and SRYbox transcription factor 2 (SOX2), which co-bind to the promoter and super-enhancer regions of the lncRNA CCAT1, regulate lineage-specific expression patterns in esophageal SCC [85]. The TP63/SOX2/CCAT1 complex activates EGFR, which activates its downstream signaling pathways in esophageal SCC [85]. MALAT1 is a classical lncRNA that mediates alternative splicing, metastasis and recurrence in several types of cancers [86]. Recent evidence suggests that MALAT1 interacts with c-MYC, and this complex binds to the Kinectin 1 promoter region to enhance EGFR protein expression in SCC [87]. The MALAT-KTN1-EGFR axis plays a pivotal role in SCC progression [87].

LncRNAs, such as epidermal growth factor-like domain-containing protein 7 (EGFL7), which increases

Table 2 Drug targets and EMT related IncRNAs in anti-cancer drug resistance

\begin{tabular}{|c|c|c|c|c|c|}
\hline IncRNAs & $\begin{array}{l}\text { Up/ } \\
\text { down }\end{array}$ & Targets & Mechanisms and function & Cancers & Refs \\
\hline $\begin{array}{l}\text { InCRNA } \\
\text { LBCS }\end{array}$ & up & $A R$ & AR activation & $\mathrm{PCa}$ & {$[73]$} \\
\hline HOXC-AS3 & up & $\begin{array}{l}\text { H3K } 4 \mathrm{me} 3 \text { and } \\
\text { H3K27 }\end{array}$ & By YBX1 regulating, promotes $\mathrm{H} 3 \mathrm{~K} 4 \mathrm{me} 3$ and $\mathrm{H} 3 \mathrm{~K} 27$ acetylation & GC & [97] \\
\hline miR503HG & Down & & & $\mathrm{HCC}$ & {$[84]$} \\
\hline HOTAIR & up & & & PCa & {$[75]$} \\
\hline CCAT1 & up & EGFR & $\begin{array}{l}\text { TP63 and SOX2 co-bind to the promoter and super-enhancer regions of } \\
\text { CCAT1 }\end{array}$ & SCC & {$[85]$} \\
\hline URRCC & up & $\begin{array}{l}\text { EGFL7/P-AKT/ } \\
\text { FOXO3 }\end{array}$ & $\begin{array}{l}\text { AKT signaling pathway } \\
\text { Proliferation and metastasis }\end{array}$ & $\mathrm{RCC}$ & {$[88]$} \\
\hline $\begin{array}{l}\text { InCRNA } \\
\text { GUARDIN }\end{array}$ & up & TRF2 & p53-responsive IncRNA & Various cancers & [98] \\
\hline Linc00210 & up & CTNNBIP1 & Wnt/ß-catenin signaling activation & liver cancer & {$[99]$} \\
\hline Linc00659 & up & cycle-related genes & & $\begin{array}{l}\text { colorectal } \\
\text { cancer }\end{array}$ & [100] \\
\hline LINC01133 & up & APC & Wnt/ß-catenin pathway & gastric cancer & [101] \\
\hline
\end{tabular}


Table 3 LncRNAs with an epigenetic function in cancer

\begin{tabular}{|c|c|c|c|}
\hline Name & Cancer & Mechanism & Ref. \\
\hline ecCEBPA & $\begin{array}{l}\text { Upregulated in gastric cancer; inverse correlation with CEBPA in } \\
\text { leukaemia cell lines. }\end{array}$ & association with DNMT1 regulates DNA methylation & $\begin{array}{l}{[106-} \\
108]\end{array}$ \\
\hline Xist & Abnormal expression in hematologic cancer. & $\begin{array}{l}\text { (1) influences } X \text { reactivation and results in genome-wide } \\
\text { changes; (2)directly interacts with SHARP to silence tran- } \\
\text { scription through HDAC3; (3) binds PRC2(the epigenetic } \\
\text { complex responsible for trimethylation of histone H3 lysine } \\
27 \text { methylation), and targets PRC2 to Xi; }\end{array}$ & $\begin{array}{l}{[109-} \\
111]\end{array}$ \\
\hline
\end{tabular}

HOTAIR Upregulated in epithelial cancer cells, such as primary breast tumors and metastases, gastric cancer, oral squamous cell carcinoma glioblastoma multiforme, colorectal cancer, esophageal squamous cell carcinoma etc., and promotes cancer metastasis.

H19 Upregulated in different cancer types, such as colorectal cancer, breast cancer, ovarian cancer cells, etc., and promotes oncogenesis and drug resistance.

MITA1 A new identified energy stress-inducible IncRNA that promotes hepatocellular carcinoma metastasis

TARID Deregulated in various human cancers

MALAT1 Upregulated in lung cancer, gastric cancer, colorectal cancer, hepatocellular carcinoma, thoracic aortic aneurysm; Deregulated in breast cancer

NEAT1 Upregulated in lung cancer

ANRIL High expression linked to poor outcome. ANRIL was identified as an oncogene in a number of tumors such as acute myeloid leukemia, gastric cancer, lung cancer, hepatocellular carcinoma, and esophageal squamous cell carcinoma.

AFAP1- High expression linked to poor outcome in non-small cell lung AS1 cancer
(1) Induces genome-wide re-targeting of PRC2 to an occu- [112pancy pattern, leading to altered histone $\mathrm{H} 3$ lysine 27 methylation, and increased cancer invasiveness and metastasis in a manner dependent on PRC2. (2HOTAIR promotes EMT by switching histone $\mathrm{H} 3$ lysine 27 acetylation to methylation at the $\mathrm{E}$ cadherin promoter, which induces the transcriptional inhibition of E cadherin. (3)interacts with PRC2 and LSD1 complex, and as a histone scaffold, to inhibit the transcription of the HOXD cluster

(1) Interacts with SAHH to regulate the DNMT3B dependent DNA methylation at different genetic loci. (2) The impact of $\mathrm{H} 19$ on metastasis could be due to the sequestration of different microRNAs

MITA1 may regulate the transcription of Slug to promote the epithelial-mesenchymal transition

Recruits the DNA demethylation regulator, GADD45a, to activate the transcription of the tumor suppressor gene, TCF21.

GADD45A is an epigenetic R-loop reader that recruits the demethylation machinery to promoter CGIs.

(1) Oct4 transcriptionally activates MALAT1 via enhancer binding to promote cell proliferation and motility, causing lung tumorigenesis and poor prognosis. (2) MALAT1 acts as a competing endogenous RNA for miR-23b-3p and attenuates the inhibitory effect of miR-23b-3p in GC cells. (3) the rs664589 $\mathrm{G}$ allele alters the binding of MALAT1 to miR-194$5 p$, resulting in increased expression of MALAT1 in colorectal cancer; (4) MALAT1 regulates cancer glucose metabolism, enhancing glycolysis, and inhibiting gluconeogenesis via elevated translation of the transcription factor TCF7L2. (5) MALAT1 binds and inactivates the prometastatic transcription factor TEAD, preventing TEAD from associating with its co-activator, YAP, and target gene promoters in breast cancer. (6) interacts with DBC1 to regulate $\mathrm{p} 53$ acetylation. (7) The HDAC9-MALAT1-BRG1 complex binds chromatin and represses contractile protein gene expression in association with gain of histone H3-lysine 27 trimethylation modifications.

Oct4 transcriptionally activates NEAT1 via promoter binding to facilitate cell proliferation and motility, causing lung tumorigenesis and poor prognosis.

(1) represses the expression of adiponectin receptor (AdipoR1), which is a key regulator of glucose metabolism, which affects the phosphorylation of AMPK and SIRT1. (2) represses KLF2 transcription by binding to PRC2 and recruiting it to the KLF2 promoter region.

AFAP1-AS1 interacts with EZH2 and recruits EZH2 to the promoter regions of p21, epigenetically repressing p21 expression.

[12,

.




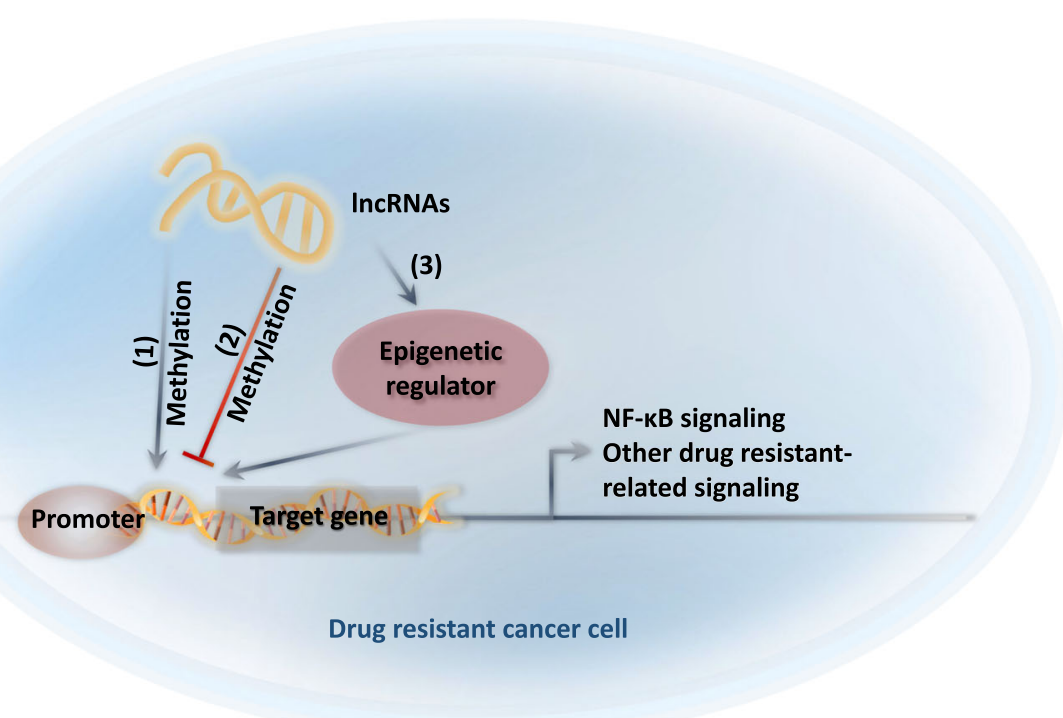

Fig. 4 Schematic illustration of the effect of IncRNAs on gene expression

the acetylation of EGFL7 at the histone $\mathrm{H} 3$ residue, increasing Akt signaling, while inhibiting FOXO3 signaling, facilitating RCC proliferation and invasion in RCC [88].

\section{EMT and exosomal IncRNA in cancer}

Exosomes are 30-100 nm in diameter, composed of proteins, RNA, and DNA [89], and are secreted by extracellular vesicles and released by exocytosis [90]. Exosomal noncoding RNAs have been found in the blood, urine, breast milk, saliva, and various tissues [91]. There is increasing evidence indicating that exosomal RNAs are present in various cancers and they enhance cancer progression, invasion, metastasis and tumorigenesis [92]. The levels of IncRNAs can be either increased or decreased in exosomes from cancer-associated fibroblasts (CAFs), which facilitate the transition of cancer cells to the EMT [90] (Fig. 3).

The metastasis of cancer cells can be affected by exosomal lncRNAs. For example, the exosomal FMR1 antisense

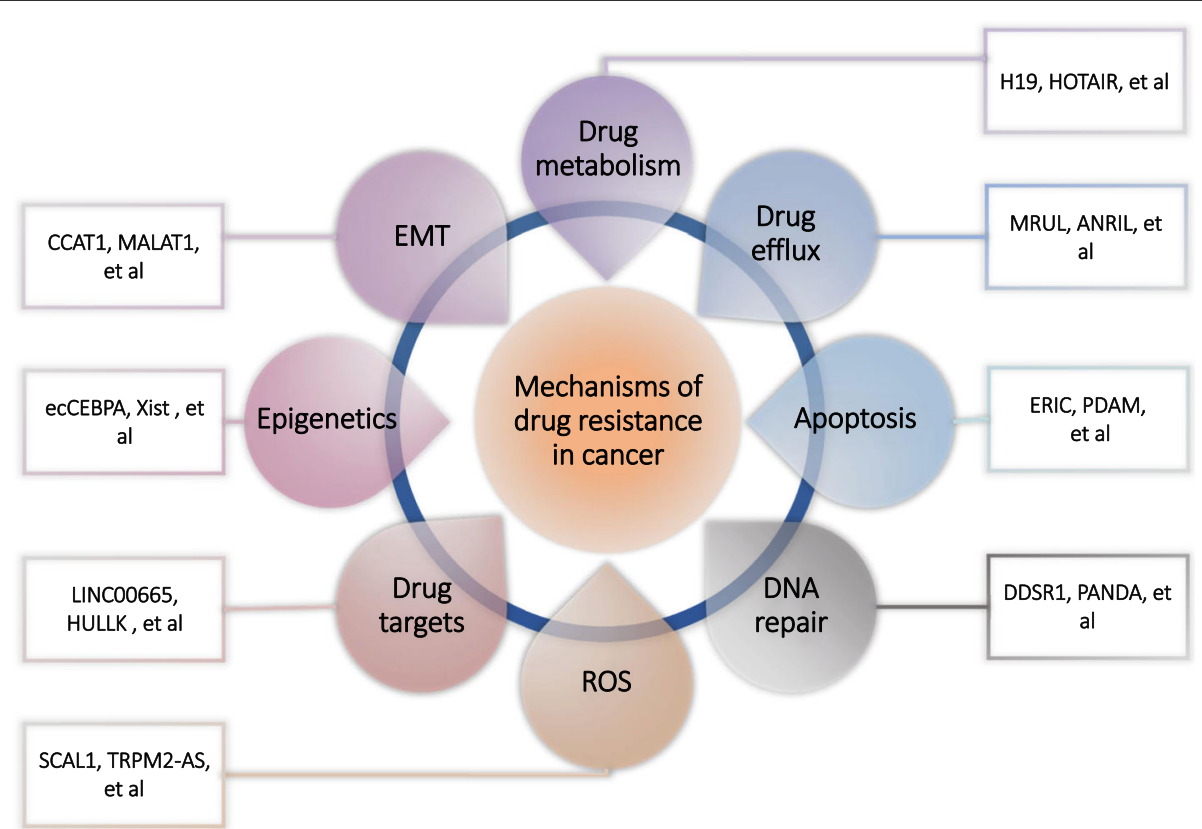

Fig. 5 Schematic illustration of the effect of IncRNAs on drug resistant cancer cells 
RNA1, FMR1-AS1, in female esophageal squamous cell carcinoma (ESCC), maintains ESCC and CSC dynamic interconversion, by activating the TLR7/NFKB/c-Myc signaling pathway in ESCC [93]. Gastric cancer cells produce and secrete the exosomal HOXA distal transcript antisense RNA (HOTTIP) and it is superior to traditional biomarkers in the serum of cancer patients, such as cancer embryonic antigen (CEA), cancer antigen 19-9 and cancer antigen 72-4 [94]. The lymph node metastasis-associated transcript 2 (LNMAT2) increases lymphatic metastasis in bladder cancer, most likely by binding to the prospero homeobox 1(PROX1) promoter, where it regulates PROX1 transcription by inducing hnRNPA2B1-mediated H3 lysine 4 trimethylation, resulting in lymphangiogenesis and lymphatic metastasis [95]. Exosomes can also be affected by lncRNAs. Indeed, the lncRNA activated by the anaphase-promoting complex subunit 1 (APC1) regulator of the Wnt signaling pathway (lncRNA-APC1), which has a tumor-suppressive role in colorectal carcinoma (CRC), is activated by peroxisome proliferator-activated receptor alpha (PPAR- $\alpha$ ), which decreases the production of exosomes [96] (Table 2).

\section{Epigenetics and related IncRNAs}

It has recently been postulated that drug resistance is linked to genetic factors (drug - induced mutations) and epigenetic factors (drug - induced non-mutational alterations of gene function) [5, 102]. LncRNAs can regulate epigenetic modifications involved in cell cycle, cell differentiation, development, and pluripotency of cancers $[103,104]$. Their involvement in epigenetic processes include the recruitment of histone-modifying enzymes and DNA methyltransferases, leading to the establishment of chromatin conformation patterns that result in the specific regulation of certain genes [105]. In the material below, we discuss cancer-related lncRNAs that regulate epigenetic changes by histone modifications, DNA methylation and chromatin architecture (Table 3) (Fig. 4).

The IncRNA HOTAIR plays a role in cancer metastasis and its levels are increased in epithelial cancer cells, such as breast cancer [112], gastric cancer [113], oral squamous cell carcinoma [114], glioblastoma multiforme [115], colorectal cancer [116], and esophageal squamous cell carcinoma [117]. LncRNA H19 expression is increased in various types of cancers and it regulates DNA methylation genome wide by regulating S-adenosylhomocysteine hydrolase to promote oncogenesis and drug resistance [118]. The lncRNA extra coding CCAAT enhancer binding protein alpha (ecCEBPA) is upregulated in gastric cancer cells [106]. The lncRNA ecCEBPA regulates DNA methylation at the CEBPA gene locus due to the interaction of ecCEBPA with DNA methyltransferase 1(DNMT1) [107, 108]. The IncRNAs Xist and HOTAIR interact with the proteins polycomb repressive complex 2 (PRC2) and lysine-specific demethylase 1 (LSD1) to prevent the transcription of target genes, such as HDAC3 and E-cadherin, and regulate cancer metastasis $[109,112,113]$.

\section{Conclusions and perspectives}

Apart from altered drug metabolism, drug efflux, DNA damage repair, ROS, cell death, drug target, EMT, epigenetic factors, autophagy, oncogenes and microRNAs, IncRNAs have been shown to produce drug resistance in certain types of cancer cells. LncRNAs are also involved in many cellular and genomic process and recent research indicates their involvement in carcinogenesis. Currently, different lncRNAs have been shown to induce chemoresistance in cancer cells (Fig. 5). Further research is required to identify additional lncRNAs that may be associated with cancer cell drug resistance and delineate their roles in carcinogenesis and chemoresistance. Overall, accumulating research indicates that targeting lncRNAs may be a strategy for the treatment of drug resistance in cancer cells.

\section{Abbreviations}

5-FU: 5-fluorouracil; ABC: ATP bind cassette; AdipoR1: Adiponectin receptor; ALDH: Aldehyde dehydrogenase; ANRIL: Antisense non-coding RNA in the INK4 locus; APC1: Anaphase-promoting complex subunit 1; AR: Androgen receptor; BLACAT1: Bladder cancer associated transcript-1; CAFs: Cancerassociated fibroblasts; CEA: Cancer embryonic antigen; CHST15: Carbohydrate sulfotransferase; CRC: Colorectal carcinoma; CRPC: Castration resistant prostate cancer; CSCs: Cancer stem cells; CTBP1-AS: C-terminal binding protein 1; CUDR: Cancer upregulated drug resistant gene;

DANCR: Differentiation antagonizing non-protein coding RNA; DDSR1: DNA damage-sensitive RNA1; DNMT1: DNA methyltransferase 1; Dox/ ADR: Doxorubicin/adriamycin; ecCEBPA: Extra coding CCAAT enhancer binding protein alpha; EGFL7: Epidermal growth factor-like domaincontaining protein 7; EGFR: Epidermal growth factor receptor; EMT: Epithelialmesenchymal transition; ERIC: E2F1-regulated inhibitor of cell death; ESCC: Esophageal squamous cell carcinoma; EZH2: Enhancer of the zeste 2 polycomb repressive complex 2 subunit; GSTM3TV2: Glutathione Stransferase mu 3, transcript variant 2 and noncoding RNA; HCC: Hepatocellular cancer; HIF-1a: Hypoxia-inducible factor alpha; HNRNPA2B1: Heterogeneous nuclear ribonucleoprotein A2/B1; HOTAIR: HOX transcript antisense intergenic RNA; HOTTIP: HOXA distal transcript antisense RNA; HULLK: Hormone-upregulated IncRNA within LCK; LAT2: L-type amino acid transporter 2; LBCS: InCRNA bladder and prostate cancer suppressor; LCK: Lymphocyte-specific protein tyrosine kinase; IncRNA-ATB: Long noncoding RNA activated by TGF-Beta; IncRNAs: Long non-coding RNAs; LNMAT2: Lymph node metastasis-associated transcript 2; LSD1: Lysinespecific demethylase 1; MALAT1: Metastasis-associated lung adenocarcinoma transcript 1; MDR: Multidrug resistance; MRUL: MDR-related and upregulated IncRNA; mTOR: Mammalian target of rapamycin; NFYA: Nuclear transcription factor $Y$ subunit alpha; Nrf2: Nuclear factor erythroid 2-related factor 2; NSCLC: Non-small cell lung cancer; OLR1: Oxidized low-density lipoprotein receptor 1; PANDA: p21 associated ncRNA DNA damage activated;

PCa: Prostate cancer; PCGEM1: Prostate cancer gene expression marker 1; PDAM: p53-dependent apoptosis modulator; P-gp: p-glycoprotein; PPARa: Peroxisome proliferator-activated receptor alpha; PRC2: Polycomb repressive complex 2; PROX1: Prospero homeobox 1; PVT1: Plasmacytoma variant translocation 1; RCC: Renal cell carcinoma; ROS: Reactive oxygen species; SCAL1: Smoke and cancer-associated IncRNA-1; SCCs: Squamous cell carcinomas; SGK1: Serum and glucocorticoid-inducible kinase 1; SOX2: SRYbox transcription factor 2; TGF-beta: Transforming growth factor-beta; TKI: Tyrosine kinase inhibitor; TP63: Tumor protein p63; TRPM2-AS: Transient receptor potential cation channel subfamily $M$ member 2 antisense; UCA1: Urothelial cancer associated 1; VCR: Vincristine; VLDLR: Very low density lipoprotein receptor; XIST: X-inactive specific transcript 


\section{Acknowledgements}

This work was supported by the Shenzhen Public Service Platform on Tumor Precision Medicine and Molecular Diagnosis, and the Shenzhen Cell Therapy Public Service Platform.

\section{Authors' contributions}

$\mathrm{KL}, \mathrm{LG}, \mathrm{XM}, J \mathrm{JH}, J \mathrm{JC}, \mathrm{CZ}$, and ZSC were major contributors in preparing and writing the manuscript. CRA and ZSC edited the manuscript. All authors read and approved the final manuscript.

\section{Funding}

This work was supported by grants from the Science and Technology Foundation of Shenzhen (JCYJ20170412155231633, JCYJ20180305164128430, GJHZ2018092817160, JCYJ20180301170047864, GJHZ20180928171802117), the Shenzhen Economic and Information Committee "Innovation Chain and Industry Chain" integration special support plan project

(20180225112449943), and the National Natural Science Foundation of China (No. 81802749).

\section{Availability of data and materials}

Not applicable.

\section{Ethics approval and consent to participate} Not applicable.

\section{Consent for publication}

Not applicable.

\section{Competing interests}

The authors declare that they have no competing interests.

\section{Author details}

'The First Affiliated Hospital of Southern University of Science and Technology, The Second Clinical Medical College of Jinan University, Shenzhen People's Hospital, Shenzhen 518020, Guangdong, People's Republic of China. ${ }^{2}$ Department of Physics, Technical University of Munich, 85748 Garching, Germany. ${ }^{3}$ College of Pharmacy and Health Sciences, St. John's University, Queens, New York, NY 11439, USA. Tomas Lindahl Nobel Laureate Laboratory, Research Centre, The Seventh Affiliated Hospital, Sun Yat-sen University, Shenzhen 518107, Guangdong, People's Republic of China.

\section{Received: 12 December 2019 Accepted: 13 February 2020}

Published online: 12 March 2020

\section{References}

1. Bray F, Ferlay J, Soerjomataram I, Siegel RL, Torre LA, Jemal A. Global cancer statistics 2018: GLOBOCAN estimates of incidence and mortality worldwide for 36 cancers in 185 countries. CA Cancer J Clin. 2018;68:394-424.

2. Ethun CG, Bilen MA, Jani AB, Maithel SK, Ogan K, Master VA. Frailty and cancer: implications for oncology surgery, medical oncology, and radiation oncology. CA Cancer J Clin. 2017;67:362-77.

3. Norouzi-Barough L, Sarookhani MR, Sharifi M, Moghbelinejad S, Jangjoo S, Salehi R. Molecular mechanisms of drug resistance in ovarian cancer. J Cell Physiol. 2018;233:4546-62.

4. Alfarouk KO, Stock CM, Taylor S, Walsh M, Muddathir AK, Verduzco D, Bashir AH, Mohammed OY, Elhassan GO, Harguindey S, et al. Resistance to cancer chemotherapy: failure in drug response from ADME to P-gp. Cancer Cell Int. 2015;15:71.

5. Brown R, Curry E, Magnani L, Wilhelm-Benartzi CS, Borley J. Poised epigenetic states and acquired drug resistance in cancer. Nat Rev Cancer. 2014;14:747-53

6. Liu X, Gao Y, Lu Y, Zhang J, Li L, Yin F. Oncogenes associated with drug resistance in ovarian cancer. J Cancer Res Clin Oncol. 2015;141:381-95.

7. Ponting $C P$, Oliver PL, Reik W. Evolution and functions of long noncoding RNAs. Cell. 2009:136:629-41.

8. Gibb EA, Brown CJ, Lam WL. The functional role of long non-coding RNA in human carcinomas. Mol Cancer. 2011:10:38.

9. Wang K, Liu CY, Zhou LY, Wang JX, Wang M, Zhao B, Zhao WK, Xu SJ, Fan $\mathrm{LH}$, Zhang XJ, et al. APF IncRNA regulates autophagy and myocardial infarction by targeting miR-188-3p. Nat Commun. 2015;6:6779.
10. Cao J. The functional role of long non-coding RNAs and epigenetics. Biol Proced Online. 2014:16:11.

11. Xu C, Li CY, Kong AN. Induction of phase I, II and III drug metabolism/ transport by xenobiotics. Arch Pharm Res. 2005;28:249-68.

12. Ren J, Ding L, Zhang D, Shi G, Xu Q, Shen S, Wang Y, Wang T, Hou Y. Carcinoma-associated fibroblasts promote the stemness and chemoresistance of colorectal cancer by transferring exosomal IncRNA H19. Theranostics. 2018:8:3932-48.

13. Liu LC, Wang YL, Lin PL, Zhang X, Cheng WC, Liu SH, Chen CJ, Hung Y, Jan $\mathrm{Cl}$, Chang LC, et al. Long noncoding RNA HOTAIR promotes invasion of breast cancer cells through chondroitin sulfotransferase CHST15. Int J Cancer. 2019;145:2478-87.

14. Wang Y, Fang Z, Hong M, Yang D, Xie W. Long-noncoding RNAs (IncRNAs) in drug metabolism and disposition, implications in cancer chemoresistance. Acta Pharm Sin B. 2019:10:105-12.

15. Xiong G, Liu C, Yang G, Feng M, Xu J, Zhao F, You L, Zhou L, Zheng L, Hu Y et al. Long noncoding RNA GSTM3TV2 upregulates LAT2 and OLR1 by competitively sponging let- 7 to promote gemcitabine resistance in pancreatic cancer. J Hematol Oncol. 2019:12:97.

16. Kusuhara H, Sugiyama Y. Role of transporters in the tissue-selective distribution and elimination of drugs: transporters in the liver, small intestine, brain and kidney. J Control Release. 2002;78:43-54.

17. Hoffmann U, Kroemer HK. The ABC transporters MDR1 and MRP2: multiple functions in disposition of xenobiotics and drug resistance. Drug Metab Rev. 2004;36:669-701.

18. Wu CP, Sim HM, Huang YH, Liu YC, Hsiao SH, Cheng HW, Li YQ, Ambudkar SV, Hsu SC. Overexpression of ATP-binding cassette transporter ABCG2 as a potential mechanism of acquired resistance to vemurafenib in BRAF(V600E) mutant cancer cells. Biochem Pharmacol. 2013;85:325-34.

19. Robey RW, Medina-Perez WY, Nishiyama K, Lahusen T, Miyake K, Litman T, Senderowicz AM, Ross DD, Bates SE. Overexpression of the ATP-binding cassette half-transporter, ABCG2 (Mxr/BCrp/ABCP1), in flavopiridol-resistant human breast cancer cells. Clin Cancer Res. 2001;7:145-52.

20. Chen Z, Shi T, Zhang L, Zhu P, Deng M, Huang C, Hu T, Jiang L, Li J. Mammalian drug efflux transporters of the ATP binding cassette (ABC) family in multidrug resistance: a review of the past decade. Cancer Lett. 2016;370:153-64.

21. Tsang WP, Kwok TT. Riboregulator H19 induction of MDR1-associated drug resistance in human hepatocellular carcinoma cells. Oncogene. 2007;26: 4877-81.

22. Takahashi K, Yan IK, Wood J, Haga H, Patel T. Involvement of extracellular vesicle long noncoding RNA (linc-VLDLR) in tumor cell responses to chemotherapy. Mol Cancer Res. 2014;12:1377-87.

23. Zhang XW, Bu P, Liu L, Zhang XZ, Li J. Overexpression of long non-coding RNA PVT1 in gastric cancer cells promotes the development of multidrug resistance. Biochem Biophys Res Commun. 2015;462:227-32.

24. Wang Y, Zhang D, Wu K, Zhao Q, Nie Y, Fan D. Long noncoding RNA MRUL promotes $A B C B 1$ expression in multidrug-resistant gastric cancer cell sublines. Mol Cell Biol. 2014;34:3182-93.

25. Hang Q, Sun R, Jiang C, Li Y. Notch 1 promotes cisplatin-resistant gastric cancer formation by upregulating IncRNA AK022798 expression. Anti-Cancer Drugs. 2015;26:632-40

26. Fang Z, Chen W, Yuan Z, Liu X, Jiang H. LncRNA-MALAT1 contributes to the cisplatin-resistance of lung cancer by upregulating MRP1 and MDR1 via STAT3 activation. Biomed Pharmacother. 2018:101:536-42.

27. Lan WG, Xu DH, Xu C, Ding CL, Ning FL, Zhou YL, Ma LB, Liu CM, Han X. Silencing of long non-coding RNA ANRIL inhibits the development of multidrug resistance in gastric cancer cells. Oncol Rep. 2016;36:263-70.

28. Ren K, Xu R, Huang J, Zhao J, Shi W. Knockdown of long non-coding RNA KCNQ1OT1 depressed chemoresistance to paclitaxel in lung adenocarcinoma. Cancer Chemother Pharmacol. 2017;80:243-50.

29. Zhu J, Zhang R, Yang D, Li J, Yan X, Jin K, Li W, Liu X, Zhao J, Shang W, Yu T. Knockdown of long non-coding RNA XIST inhibited doxorubicin resistance in colorectal cancer by upregulation of miR-124 and downregulation of SGK1. Cell Physiol Biochem. 2018;51:113-28.

30. Chang L, Hu Z, Zhou Z, Zhang H. Linc00518 contributes to multidrug resistance through regulating the MiR-199a/MRP1 axis in breast cancer. Cell Physiol Biochem. 2018:48:16-28.

31. Wu X, Zheng Y, Han B, Dong X. Long noncoding RNA BLACAT1 modulates $A B C B 1$ to promote oxaliplatin resistance of gastric cancer via sponging miR361. Biomed Pharmacother. 2018;99:832-8. 
32. Marquez RT, Tsao BW, Faust NF, Liang X. Drug resistance and molecular cancer therapy: apoptosis versus autophagy; 2013.

33. Mohammad RM, Muqbil I, Lowe L, Yedjou C, Hsu HY, Lin LT, Siegelin MD, Fimognari C, Kumar NB, Dou QP, et al. Broad targeting of resistance to apoptosis in cancer. Semin Cancer Biol. 2015;35(Suppl):S78-s103.

34. Feldstein O, Nizri T, Doniger T, Jacob J, Rechavi G, Ginsberg D. The long non-coding RNA ERIC is regulated by E2F and modulates the cellular response to DNA damage. Mol Cancer. 2013;12:131.

35. Pang JC, Li KK, Lau KM, Ng YL, Wong J, Chung NY, Li HM, Chui YL, Lui WW, Chen ZP, et al. KIAA0495/PDAM is frequently downregulated in oligodendroglial tumors and its knockdown by siRNA induces cisplatin resistance in glioma cells. Brain Pathol. 2010;20:1021-32.

36. Fu X, Ravindranath L, Tran N, Petrovics G, Srivastava S. Regulation of apoptosis by a prostate-specific and prostate cancer-associated noncoding gene, PCGEM1. DNA Cell Biol. 2006;25:135-41.

37. Wang Y, Chen W, Yang C, Wu W, Wu S, Qin X, Li X. Long non-coding RNA UCA1a(CUDR) promotes proliferation and tumorigenesis of bladder cancer. Int J Oncol. 2012;41:276-84.

38. Malek E, Jagannathan S, Driscoll JJ. Correlation of long non-coding RNA expression with metastasis, drug resistance and clinical outcome in cancer. Oncotarget. 2014:5:8027-38.

39. Majidinia M, Sadeghpour A, Mehrzadi S, Reiter RJ, Khatami N, Yousefi B. Melatonin: a pleiotropic molecule that modulates DNA damage response and repair pathways. J Pineal Res. 2017;63.

40. Salehan MR, Morse HR. DNA damage repair and tolerance: a role in chemotherapeutic drug resistance. Br J Biomed Sci. 2013;70:31-40.

41. Ozes AR, Miller DF, Ozes ON, Fang F, Liu Y, Matei D, Huang T, Nephew KP. NF-kappaB-HOTAIR axis links DNA damage response, chemoresistance and cellular senescence in ovarian cancer. Oncogene. 2016;35:5350-61.

42. Wang L, Ma L, Xu F, Zhai W, Dong S, Yin L, Liu J, Yu Z. Role of long non-coding RNA in drug resistance in non-small cell lung cancer. Thorac Cancer. 2018;9:761-8.

43. Burdett S. Adjuvant chemotherapy for resected early-stage non-small cell lung cancer. 2015;3:CD011430.

44. Sharma V, Khurana S, Kubben N, Abdelmohsen K, Oberdoerffer P, Gorospe M, Misteli T. A BRCA 1-interacting Inc RNA regulates homologous recombination. 2015;16:1520-34.

45. Dolfini D, Mantovani R. Targeting the Y/CCAAT box in cancer: YB-1 (YBX1) or NF-Y? Cell Death \& Differentiation. 20:676-85.

46. Hung T, Wang Y, Lin MF, Koegel AK, Kotake Y, Grant GD, Horlings HM, Shah $\mathrm{N}$, Umbricht $\mathrm{C}$, Wang $\mathrm{P}$, et al. Extensive and coordinated transcription of noncoding RNAs within cell-cycle promoters. Nat Genet. 2011;43:621-9.

47. Liu Z, Sun M, Lu K, Liu J, Zhang M, Wu W, De W, Wang Z, Wang R. The long noncoding RNA HOTAIR contributes to cisplatin resistance of human lung adenocarcinoma cells via downregualtion of p21(WAF1/CIP1) expression. PLoS One. 2013;8:e77293.

48. Karimian A, Ahmadi Y, Yousefi B. Multiple functions of p21 in cell cycle, apoptosis and transcriptional regulation after DNA damage. DNA Repair (Amst). 2016;42:63-71.

49. Sabharwal SS, Schumacker PT. Mitochondrial ROS in cancer: initiators, amplifiers or an Achilles' heel? Nat Rev Cancer. 2014;14:709-21.

50. Di Domenico F, Perluigi M, Butterfield DA, Cornelius C, Calabrese V. Oxidative damage in rat brain during aging: interplay between energy and metabolic key target proteins. Neurochem Res. 2010;35:2184-92.

51. Nunomura A, Moreira PI, Castellani RJ, Lee HG, Zhu X, Smith MA, Perry G. Oxidative damage to RNA in aging and neurodegenerative disorders. Neurotox Res. 2012;22:231-48.

52. Reuter S, Gupta SC, Chaturvedi MM, Aggarwal BB. Oxidative stress, inflammation, and cancer: how are they linked? Free Radic Biol Med. 2010; 49:1603-16.

53. Thai P, Statt S, Chen CH, Liang E, Campbell C, Wu R. Characterization of a novel long noncoding RNA, SCAL1, induced by cigarette smoke and elevated in lung cancer cell lines. Am J Respir Cell Mol Biol. 2013;49:204-11.

54. Sajadimajd S, Khazaei M. Oxidative stress and cancer: the role of Nrf2. Curr Cancer Drug Targets. 2018;18:538-57.

55. Orfanelli U, Jachetti E, Chiacchiera F, Grioni M, Brambilla P, Briganti A, Freschi M, Martinelli-Boneschi F, Doglioni C, Montorsi F, et al. Antisense transcription at the TRPM2 locus as a novel prognostic marker and therapeutic target in prostate cancer. Oncogene. 2015;34:2094-102.

56. Chen SJ, Zhang W, Tong Q, Conrad K, Hirschler-Laszkiewicz I, Bayerl M, Kim JK, Cheung JY, Miller BA. Role of TRPM2 in cell proliferation and susceptibility to oxidative stress. Am J Physiol Cell Physiol. 2013;304:C548-60.
57. Bai JZ, Lipski J. Differential expression of TRPM2 and TRPV4 channels and their potential role in oxidative stress-induced cell death in organotypic hippocampal culture. Neurotoxicology. 2010;31:204-14.

58. Liu Z, Ming S, Kaihua L, Jing L, Meiling Z, Weigin W, Wei D, Zhaoxia W, Ru W, Vladimir VK. The long noncoding RNA HOTAIR contributes to cisplatin resistance of human lung adenocarcinoma cells via downregualtion of p21WAF1/CIP1 expression. Plos One. 8:e77293.

59. Zheng X, Carstens JL, Kim J, Scheible M, Kaye J, Sugimoto H, Wu CC, LeBleu VS, Kalluri R. Epithelial-to-mesenchymal transition is dispensable for metastasis but induces chemoresistance in pancreatic cancer. Nature. 2015;527:525-30.

60. Neelakantan D, Zhou H, Oliphant MUJ, Zhang X, Simon LM, Henke DM, Shaw CA, Wu MF, Hilsenbeck SG, White LD, et al. EMT cells increase breast cancer metastasis via paracrine GLI activation in neighbouring tumour cells. Nat Commun. 2017:8:15773.

61. Lovf M, Zhao S, Axcrona U, Johannessen B, Bakken AC, Carm KT, Hoff AM, Myklebost O, Meza-Zepeda LA, Lie AK, et al. Multifocal primary prostate cancer exhibits high degree of genomic heterogeneity. Eur Urol. 2019;75:498-505.

62. Xiong XD, Ren X, Cai MY, Yang JW, Liu X, Yang JM. Long non-coding RNAs: an emerging powerhouse in the battle between life and death of tumor cells. Drug Resist Updat. 2016;26:28-42.

63. Fischer KR, Durrans A, Lee S, Sheng J, Li F, Wong ST, Choi H, El Rayes T, Ryu $\mathrm{S}$, Troeger J, et al. Epithelial-to-mesenchymal transition is not required for lung metastasis but contributes to chemoresistance. Nature. 2015;527:472-6.

64. Wang B, Jiang H, Wang L, Chen X, Wu K, Zhang S, Ma S, Xia B. Increased MIR31HG IncRNA expression increases gefitinib resistance in non-small cell lung cancer cell lines through the EGFR/PI3K/AKT signaling pathway. Oncol Lett. 2017;13:3494-500.

65. Minari R, Bordi P, Tiseo M. Third-generation epidermal growth factor receptor-tyrosine kinase inhibitors in T790M-positive non-small cell lung cancer: review on emerged mechanisms of resistance. Transl Lung Cancer Res. 2016;5:695-708

66. Boccaccio C, Luraghi P, Comoglio PM. MET-mediated resistance to EGFR inhibitors: an old liaison rooted in colorectal cancer stem cells. Cancer Res. 2014;74:3647-51.

67. Cao W, Liu Y, Zhang R, Zhang B, Wang T, Zhu X, Mei L, Chen H, Zhang H, Ming P, Huang L. Homoharringtonine induces apoptosis and inhibits STAT3 via IL-6/JAK1/STAT3 signal pathway in Gefitinib-resistant lung cancer cells. Sci Rep. 2015;5:8477.

68. Kim TM, Song A, Kim DW, Kim S, Ahn YO, Keam B, Jeon YK, Lee SH, Chung DH, Heo DS. Mechanisms of acquired resistance to AZD9291: a mutationselective, irreversible EGFR inhibitor. J Thorac Oncol. 2015;10:1736-44.

69. Park JH, Choi YJ, Kim SY, Lee JE, Sung KJ, Park S, Kim WS, Song JS, Choi CM, Sung YH, et al. Activation of the IGF1R pathway potentially mediates acquired resistance to mutant-selective 3rd-generation EGF receptor tyrosine kinase inhibitors in advanced non-small cell lung cancer. Oncotarget. 2016;7:22005-15.

70. Chabon JJ, Simmons AD, Lovejoy AF, Esfahani MS, Newman AM, Haringsma HJ, Kurtz DM, Stehr H, Scherer F, Karlovich CA, et al. Circulating tumour DNA profiling reveals heterogeneity of EGFR inhibitor resistance mechanisms in lung cancer patients. Nat Commun. 2016;7:11815.

71. Yao Z, Fenoglio S, Gao DC, Camiolo M, Stiles B, Lindsted T, Schlederer M, Johns C, Altorki N, Mittal V, et al. TGF-beta IL-6 axis mediates selective and adaptive mechanisms of resistance to molecular targeted therapy in lung cancer. Proc Natl Acad Sci U S A. 2010;107:15535-40.

72. Liu X, Lu X, Zhen F, Jin S, Yu T, Zhu Q, Wang W, Xu K, Yao J, Guo R. LINC00665 induces acquired resistance to Gefitinib through recruiting EZH2 and activating PI3KJAKT pathway in NSCLC. Mol Ther Nucleic Acids. 2019;16:155-61.

73. Gu P, Chen X, Xie R, Xie W, Huang L, Dong W, Han J, Liu X, Shen J, Huang J, Lin T. A novel AR translational regulator IncRNA LBCS inhibits castration resistance of prostate cancer. Mol Cancer. 2019;18:109.

74. Jin HJ, Zhao JC, Wu L, Kim J, Yu J. Cooperativity and equilibrium with FOXA1 define the androgen receptor transcriptional program. Nat Commun. 2014;5:3972

75. Zhang A, Zhao JC, Kim J, Fong KW, Yang YA, Chakravarti D, Mo YY, Yu J. LncRNA HOTAIR enhances the androgen-receptor-mediated transcriptional program and drives castration-resistant prostate Cancer. Cell Rep. 2015;13: 209-21.

76. Xu S, Yi XM, Tang CP, Ge JP, Zhang ZY, Zhou WQ. Long non-coding RNA ATB promotes growth and epithelial-mesenchymal transition and predicts poor prognosis in human prostate carcinoma. Oncol Rep. 2016;36:10-22. 
77. Kretz M, Webster DE, Flockhart RJ, Lee CS, Zehnder A, Lopez-Pajares V, Qu K, Zheng GX, Chow J, Kim GE, et al. Suppression of progenitor differentiation requires the long noncoding RNA ANCR. Genes Dev. 2012;26:338-43.

78. Heer R, Robson CN, Shenton BK, Leung HY. The role of androgen in determining differentiation and regulation of androgen receptor expression in the human prostatic epithelium transient amplifying population. J Cell Physiol. 2007;212:572-8.

79. Zhang Z, Zhou N, Huang J, Ho TT, Zhu Z, Qiu Z, Zhou X, Bai C, Wu F, Xu M, Mo YY. Regulation of androgen receptor splice variant AR3 by PCGEM1. Oncotarget. 2016;7:15481-91.

80. Takayama K, Horie-Inoue K, Katayama S, Suzuki T, Tsutsumi S, Ikeda K, Urano T, Fujimura T, Takagi K, Takahashi S, et al. Androgen-responsive long noncoding RNA CTBP1-AS promotes prostate cancer. EMBO J. 2013;32:1665-80.

81. Ta HQ, Whitworth H, Yin Y, Conaway M, Frierson HF Jr, Campbell MJ, Raj GV, Gioeli D. Discovery of a novel long noncoding RNA overlapping the LCK gene that regulates prostate cancer cell growth. Mol Cancer. 2019;18:113.

82. Dave B, Mittal V, Tan NM, Chang JC. Epithelial-mesenchymal transition, cancer stem cells and treatment resistance. Breast Cancer Res. 2012;14:202.

83. Du B, Shim JS. Targeting epithelial-Mesenchymal transition (EMT) to overcome drug resistance in Cancer. Molecules. 2016;21.

84. Wang $H$, Liang L, Dong Q, Huan L, He J, Li B, Yang C, Jin H, Wei L, Yu C, et al. Long noncoding RNA miR503HG, a prognostic indicator, inhibits tumor metastasis by regulating the HNRNPA2B1/NF-kappaB pathway in hepatocellular carcinoma. Theranostics. 2018;8:2814-29.

85. Jiang Y, Jiang YY, Xie JJ, Mayakonda A, Hazawa M, Chen L, Xiao JF, Li CQ, Huang ML, Ding LW, et al. Co-activation of super-enhancer-driven CCAT1 by TP63 and SOX2 promotes squamous cancer progression. Nat Commun. 2018;9:3619.

86. Li ZX, Zhu QN, Zhang HB, Hu Y, Wang G, Zhu YS. MALAT1: a potential biomarker in cancer. Cancer Manag Res. 2018;10:6757-68.

87. Zhang Y, Gao L, Ma S, Ma J, Wang Y, Li S, Hu X, Han S, Zhou M, Zhou L, Ding Z. MALAT1-KTN1-EGFR regulatory axis promotes the development of cutaneous squamous cell carcinoma. Cell Death Differ. 2019;26:2061-73.

88. Zhai W, Zhu R, Ma J, Gong D, Zhang H, Zhang J, Chen Y, Huang Y, Zheng J, Xue W. A positive feed-forward loop between LnCRNA-URRCC and EGFL7/PAKT/FOXO3 signaling promotes proliferation and metastasis of clear cell renal cell carcinoma. Mol Cancer. 2019;18:81.

89. Melo SA, Sugimoto H, O'Connell JT, Kato N, Villanueva A, Vidal A, Qiu L, Vitkin E, Perelman LT, Melo CA, et al. Cancer exosomes perform cellindependent microRNA biogenesis and promote tumorigenesis. Cancer Cell. 2014; $26: 707-21$

90. Xie Y, Dang W, Zhang S, Yue W, Yang L, Zhai X, Yan Q, Lu J. The role of exosomal noncoding RNAs in cancer. Mol Cancer. 2019;18:37.

91. Zhou Y, Xia L, Lin J, Wang H, Oyang L, Tan S, Tian Y, Su M, Wang H, Cao D, Liao Q. Exosomes in nasopharyngeal carcinoma. J Cancer. 2018;9:767-77.

92. Bebelman MP, Smit MJ, Pegtel DM, Baglio SR. Biogenesis and function of extracellular vesicles in cancer. Pharmacol Ther. 2018;188:1-11.

93. Li W, Zhang L, Guo B, Deng J, Wu S, Li F, Wang Y, Lu J, Zhou Y. Exosomal FMR1-AS1 facilitates maintaining cancer stem-like cell dynamic equilibrium via TLR7/NFkappaB/c-Myc signaling in female esophageal carcinoma. Mol Cancer. 2019;18:22

94. Zhao R, Zhang Y, Zhang X, Yang Y, Zheng X, Li X, Liu Y, Zhang Y. Exosomal long noncoding RNA HOTTIP as potential novel diagnostic and prognostic biomarker test for gastric cancer. Mol Cancer. 2018;17:68.

95. Chen C, Luo Y, He W, Zhao Y, Kong Y, Liu H, Zhong G, Li Y, Li J, Huang J, et al. Exosomal long noncoding RNA LNMAT2 promotes lymphatic metastasis in bladder cancer. J Clin Invest. 2019.

96. Wang FW, Cao CH, Han K, Zhao YX, Cai MY, Xiang ZC, Zhang JX, Chen JW, Zhong LP, Huang $Y$, et al. APC-activated long noncoding RNA inhibits colorectal carcinoma pathogenesis through reduction of exosome production. J Clin Invest. 2019;129:727-43.

97. Zhang E, He X, Zhang C, Su J, Lu X, Si X, Chen J, Yin D, Han L, De W. A novel long noncoding RNA HOXC-AS3 mediates tumorigenesis of gastric cancer by binding to YBX1. Genome Biol. 2018;19:154.

98. Hu WL, Jin L, Xu A, Wang YF, Thorne RF, Zhang XD, Wu M. GUARDIN is a p53-responsive long non-coding RNA that is essential for genomic stability. Nat Cell Biol. 2018;20:492-502.

99. Fu X, Zhu X, Qin F, Zhang Y, Lin J, Ding Y, Yang Z, Shang Y, Wang L, Zhang Q, Gao Q. Linc00210 drives Wnt/beta-catenin signaling activation and liver tumor progression through CTNNBIP1-dependent manner. Mol Cancer. 2018;17:73.
100. Tsai KW, Lo YH, Liu H, Yeh CY, Chen YZ, Hsu CW, Chen WS, Wang JH. Linc00659, a long noncoding RNA, acts as novel oncogene in regulating cancer cell growth in colorectal cancer. Mol Cancer. 2018;17:72.

101. Yang XZ, Cheng TT, He QJ, Lei ZY, Chi J, Tang Z, Liao QX, Zhang H, Zeng LS, Cui SZ. LINC01133 as ceRNA inhibits gastric cancer progression by sponging miR-106a-3p to regulate APC expression and the Wnt/betacatenin pathway. Mol Cancer. 2018;17:126.

102. Easwaran H, Tsai HC, Baylin SB. Cancer epigenetics: tumor heterogeneity, plasticity of stem-like states, and drug resistance. Mol Cell. 2014;54:716-27.

103. Xiao Y, Su M, Ou W, Wang H, Tian B, Ma J, Tang J, Wu J, Wu Z, Wang W Zhou Y. Involvement of noncoding RNAs in epigenetic modifications of esophageal cancer. Biomed Pharmacother. 2019;117:109192.

104. Kurokawa R, Rosenfeld MG, Glass CK. Transcriptional regulation through noncoding RNAs and epigenetic modifications. RNA Biol. 2009;6:233-6.

105. Beckedorff FC, Amaral MS, Deocesano-Pereira C, Verjovski-Almeida S. Long noncoding RNAs and their implications in cancer epigenetics. Biosci Rep. 2013;33.

106. Nasrollahzadeh-Khakiani M, Emadi-Baygi M, Nikpour P. Augmented expression levels of IncRNAs ecCEBPA and UCA1 in gastric cancer tissues and their clinical significance. Iran J Basic Med Sci. 2017;20:1149-58.

107. Di Ruscio A, Ebralidze AK, Benoukraf T, Amabile G, Goff LA, Terragni J, Figueroa ME, De Figueiredo Pontes $L L$, Alberich-Jorda M, Zhang $P$, et al. DNMT1-interacting RNAs block gene-specific DNA methylation. Nature. 2013;503:371-6.

108. Lai F, Shiekhattar R. Where long noncoding RNAs meet DNA methylation. Cell Res. 2014;24:263-4.

109. Yildirim E, Kirby JE, Brown DE, Mercier FE, Sadreyev RI, Scadden DT, Lee JT. Xist RNA is a potent suppressor of hematologic cancer in mice. Cell. 2013; 152:727-42.

110. McHugh CA, Chen CK, Chow A, Surka CF, Tran C, McDonel P, Pandya-Jones A, Blanco M, Burghard C, Moradian A, et al. The Xist IncRNA interacts directly with SHARP to silence transcription through HDAC3. Nature. 2015; 521:232-6.

111. Lee JT. Epigenetic regulation by long noncoding RNAs. Science. 2012;338: 1435-9.

112. Gupta RA, Shah N, Wang KC, Kim J, Horlings HM, Wong DJ, Tsai MC, Hung T, Argani P, Rinn JL, et al. Long non-coding RNA HOTAIR reprograms chromatin state to promote cancer metastasis. Nature. 2010;464:1071-6.

113. Song Y, Wang R, Li LW, Liu X, Wang YF, Wang QX, Zhang Q. Long noncoding RNA HOTAIR mediates the switching of histone $\mathrm{H} 3$ lysine 27 acetylation to methylation to promote epithelial-to-mesenchymal transition in gastric cancer. Int J Oncol. 2019;54:77-86.

114. Wu Y, Zhang L, Zhang L, Wang Y, Li H, Ren X, Wei F, Yu W, Liu T, Wang X, et al. Long non-coding RNA HOTAIR promotes tumor cell invasion and metastasis by recruiting EZH2 and repressing E-cadherin in oral squamous cell carcinoma. Int J Oncol. 2015;46:2586-94.

115. Tan SK, Pastori C, Penas C, Komotar RJ, Ivan ME, Wahlestedt C, Ayad NG. Serum long noncoding RNA HOTAIR as a novel diagnostic and prognostic biomarker in glioblastoma multiforme. Mol Cancer. 2018;17:74.

116. Okugawa Y, Grady WM, Goel A. Epigenetic alterations in colorectal Cancer: emerging biomarkers. Gastroenterology. 2015;149:1204-25 e1212.

117. Wang W, He X, Zheng Z, Ma X, Hu X, Wu D, Wang M. Serum HOTAIR as a novel diagnostic biomarker for esophageal squamous cell carcinoma. Mol Cancer. 2017;16:75.

118. Zhou J, Yang L, Zhong T, Mueller M, Men Y, Zhang N, Xie J, Giang K, Chung $H$, Sun $X$, et al. H19 IncRNA alters DNA methylation genome wide by regulating S-adenosylhomocysteine hydrolase. Nat Commun. 2015;6:10221.

119. Medrzycki M, Zhang Y, Zhang W, Cao K, Pan C, Lailler N, McDonald JF, Bouhassira EE, Fan Y. Histone h1.3 suppresses h19 noncoding RNA expression and cell growth of ovarian cancer cells. Cancer Res. 2014;74: 6463-73.

120. Yoshimura H, Matsuda Y, Yamamoto M, Kamiya S, Ishiwata T. Expression and role of long non-coding RNA H19 in carcinogenesis. Front Biosci. 2018;23: 614-25.

121. Li Z, Li Y, Li Y, Ren K, Li X, Han X, Wang J. Long non-coding RNA H19 promotes the proliferation and invasion of breast cancer through upregulating DNMT1 expression by sponging miR-152. J Biochem Mol Toxicol. 2017;31

122. Ma M, Xu H, Liu G, Wu J, Li C, Wang X, Zhang S, Xu H, Ju S, Cheng W, et al. Metabolism-induced tumor activator 1 (MITA1), an energy stress-inducible long noncoding RNA, promotes hepatocellular carcinoma metastasis. Hepatology. 2019;70:215-30. 
123. Arab K, Park YJ, Lindroth AM, Schafer A, Oakes C, Weichenhan D, Lukanova A, Lundin E, Risch A, Meister M, et al. Long noncoding RNA TARID directs demethylation and activation of the tumor suppressor TCF21 via GADD45A. Mol Cell. 2014:55:604-14.

124. Arab K, Karaulanov E, Musheev M, Trnka P, Schafer A, Grummt I, Niehrs C. GADD45A binds R-loops and recruits TET1 to CpG island promoters. Nat Genet. 2019;51:217-23.

125. Kim J, Piao HL, Kim BJ, Yao F, Han Z, Wang Y, Xiao Z, Siverly AN, Lawhon SE, Ton BN, et al. Long noncoding RNA MALAT1 suppresses breast cancer metastasis. Nat Genet. 2018;50:1705-15.

126. Jen J, Tang YA, Lu YH, Lin CC, Lai WW, Wang YC. Oct4 transcriptionally regulates the expression of long non-coding RNAs NEAT1 and MALAT1 to promote lung cancer progression. Mol Cancer. 2017;16:104.

127. YiRen $H$, YingCong Y, Sunwu Y, Keqin L, Xiaochun T, Senrui C, Ende C, XiZhou L, Yanfan C. Long noncoding RNA MALAT1 regulates autophagy associated chemoresistance via miR-23b-3p sequestration in gastric cancer. Mol Cancer. 2017;16:174.

128. Wu S, Sun H, Wang Y, Yang X, Meng Q, Yang H, Zhu H, Tang W, Li X, Aschner M, Chen R. MALAT1 rs664589 polymorphism inhibits binding to miR-194-5p, contributing to colorectal Cancer risk, growth, and metastasis. Cancer Res. 2019;79:5432-41.

129. Malakar P, Stein I, Saragovi A, Winkler R, Stern-Ginossar N, Berger M, Pikarsky E, Karni R. Long noncoding RNA MALAT1 regulates Cancer glucose metabolism by enhancing mTOR-mediated translation of TCF7L2. Cancer Res. 2019;79:2480-93.

130. Chen R, Liu Y, Zhuang H, Yang B, Hei K, Xiao M, Hou C, Gao H, Zhang X, Jia $C$, et al. Quantitative proteomics reveals that long non-coding RNA MALAT1 interacts with DBC1 to regulate p53 acetylation. Nucleic Acids Res. 2017;45: 9947-59.

131. Lino Cardenas CL, Kessinger CW, Cheng Y, MacDonald C, MacGillivray T, Ghoshhajra B, Huleihel L, Nuri S, Yeri AS, Jaffer FA, et al. An HDAC9-MALAT1BRG1 complex mediates smooth muscle dysfunction in thoracic aortic aneurysm. Nat Commun. 2018;9:1009.

132. Sun LY, Li XJ, Sun YM, Huang W, Fang K, Han C, Chen ZH, Luo XQ, Chen $Y Q$, Wang WT. LncRNA ANRIL regulates AML development through modulating the glucose metabolism pathway of AdipoR1/AMPK/SIRT1. Mol Cancer. 2018;17:127.

133. Li Z, Yu X, Shen J. ANRIL: a pivotal tumor suppressor long non-coding RNA in human cancers. Tumour Biol. 2016;37:5657-61.

134. Huang MD, Chen WM, Qi FZ, Xia R, Sun M, Xu TP, Yin L, Zhang EB, De W, Shu YQ. Erratum to: long non-coding RNA ANRIL is upregulated in hepatocellular carcinoma and regulates cell proliferation by epigenetic silencing of KLF2. J Hematol Oncol. 2017;10:143.

135. Huang MD, Chen WM, Qi FZ, Xia R, Sun M, Xu TP, Yin L, Zhang EB, De W, Shu YQ. Long non-coding RNA ANRIL is upregulated in hepatocellular carcinoma and regulates cell proliferation by epigenetic silencing of KLF2. J Hematol Oncol. 2015;8:57.

136. Yin D, Lu X, Su J, He X, De W, Yang J, Li W, Han L, Zhang E. Long noncoding RNA AFAP1-AS1 predicts a poor prognosis and regulates nonsmall cell lung cancer cell proliferation by epigenetically repressing p21 expression. Mol Cancer. 2018;17:92.

\section{Publisher's Note}

Springer Nature remains neutral with regard to jurisdictional claims in published maps and institutional affiliations.

\section{Ready to submit your research? Choose BMC and benefit from}

- fast, convenient online submission

- thorough peer review by experienced researchers in your field

- rapid publication on acceptance

- support for research data, including large and complex data types

- gold Open Access which fosters wider collaboration and increased citations

- maximum visibility for your research: over $100 \mathrm{M}$ website views per year

At BMC, research is always in progress.

Learn more biomedcentral.com/submissions 